\title{
Autoimmune Hemolytic Anemia
}

National Cancer Institute

\section{Source}

National Cancer Institute. Autoimmune Hemolytic Anemia. NCI Thesaurus. Code C34378

An acquired anemia caused by destruction of the red blood cells by autoantibodies.

Causes include autoimmune disorders, lymphoproliferative disorders, and infections. 